\title{
RAMUS THIRTY-FIVE YEARS
}

\section{Helen Morales}

It is a real honour to come on board as co-editor of Ramus, now in its thirtyfifth year. Thinking about the future of Ramus is an opportune moment to reflect upon where the journal has come from, and what changes have taken place for journals of classical literary criticism since the time of its inception in 1972 , and especially over the last couple of decades, around the time I first read Ramus as a student.

Ramus is an indisputably international journal. It is associated with three institutions whose support is invaluable: the University of Southern California in the USA, where Tony Boyle is Professor of Classics, the University of Cambridge in England (an intellectual debt acknowledged in the 1993 volume celebrating the 'New Cambridge Latinists'), where Tony Boyle and John Penwill have been visitors for many years and where I work, and La Trobe University, Bendigo, Australia, which is John Penwill's base and where Ramus is published by Aureal Publications. Its contributors, readers, and subscribers also reflect its internationalism. But Ramus has always been and will remain free of institutional control and institutional restraints. The history of Ramus represents the realisation of a vision, that of the founding editor, Tony Boyle, supported at its inception by his Monash University colleague Gerald Fitzgerald, then for more than three decades by John Penwill (whose recent election as President of the Australasian Society for Classical Studies is in recognition of his advancement of studies in ancient literature, not least in his role as Associate Editor and Business Manager of Ramus). This vision, shared in fact by all three, was to enable the publication of research that strives for a more profound understanding of classical literature through the close scrutiny of individual texts. Its emphasis is on better appreciation of the particularity of individual works and on their meaning: what makes them distinctive, significant, and worth reading.

There have been two major changes in literary criticism over the last few decades. The first is the burgeoning of 'reception studies' and the conviction that a literary work can be illuminated through examination of later adaptations and appropriations of the work, in literature, theory and art. Ramus has embraced this development, though the interest is still in greater understanding of ancient texts, not in 'reception' in any fetishised sense, 'reception' for its own sake. The second change is a greater shift towards what has become known as a 'cultural poetics' approach to literature: an approach that insists on analysing a literary text in its fullest possible contexts: historical, visual, political and philosophical. Woe betide the graduate student who goes on the job market in America these days and is 'too text-based' (a charge levelled at me after an APA interview several years ago now). It is axiomatic that an appreciation of cultural contexts (insofar as we can reconstruct them) is an essential part of literary crit- 
icism, but there are also problems with this approach. It sometimes leads to dilettantism, a superficial grappling with too much material; what I have elsewhere termed 'textual surfing' It can also on occasion lead to a dull historicism that loses sight of a work's aesthetic qualities and why it might be worth reading. Hence the continued promotion in Ramus of the close reading of literature and of reflection upon why close reading matters. Tony Boyle's and Gerald Fitzgerald's statement from their original editorial sounds a bit dated and pompous now, but it bears restating nonetheless: '...the understanding of [classical literature] not only brings with it the intellectual satisfaction common to achievement in all academic disciplines but, since it increases one's comprehension of issues fundamental to oneself as a thinking, sentient human person, contributes towards, and is constituent of, the richness of one's own experience. As the "humanity" par excellence, Greek and Roman literature define what it is to be human.'

How do we measure a journal's success? There's much discussion nowadays about the Journal Impact Factor, an ugly phrase used in the sciences as a measure of the frequency with which the 'average article' in a journal has been cited in a particular year. The Impact Factor is used to evaluate a journal's importance compared to others in the field. I very much hope that the arts and humanities do not adopt this model from the sciences (though there are whispers of its possible introduction in Britain), not because Ramus would not score highly, nor even because of the nightmare vision of scholars obsessing about how many times their work has been cited, but rather because it has been firmly documented that this method of evaluation is gender discriminatory. Studies have shown that men tend to cite articles by men more frequently than those by women and vice versa. As Classics is a field with more men in university positions than women this kind of evaluation exercise is likely to produce biased results. Ramus, alongside journals like Arethusa and Helios, has from its inception particularly encouraged contributions by women, as well as being open to theoretical perspectives more frequently adopted by women than men, such as feminism. Perhaps a better index of a journal's impact is its influence on the field as a whole. When Ramus first began, its agenda was a radical one. It is a measure of its success that it now looks more mainstream than radical. There are now several journals that showcase the close reading of literary texts, including Classical Quarterly and American Journal of Philology. Indeed the journal that perhaps today most closely resembles Ramus is Materiali e discussioni per l'analisi dei testi classici. Journal Impact Factor indeed.

One popular misconception about Ramus is that it is a journal largely devoted to studies of Latin literature. This is despite its containing a good balance of contributions on Greek and Latin literature, from the very first issue which had articles on Hellenistic poetry and Greek tragedy (by Charles Segal, James McCaughey and Arthur McDevitt) to the recent special issue on ekphrasis in Greek and Latin literature (guest edited by Jaś Elsner). (An index to all articles in Ramus can be found at the URL shown on the information page). This must 


\section{RAMUS THIRTY-FIVE YEARS}

largely be due to the identification of the journal with its editors (both Boyle and Penwill are Latinists). I am largely a Hellenist, whose research includes work on Roman oratory and late antique poetry, but which has largely centred on the ancient Greek novel (see, by way of introduction, my piece on Iamblichus' Babylonian Tales below). Hopefully, having a Hellenist on the editorial team will help correct this misconception. Future special issues in the pipeline include, in addition to one on Apuleius, one on late antique Greek poetry and one on literary approaches to Josephus.

Ramus relies upon its dedicated team of readers in Europe, North America, and Australasia. This is a fitting moment to thank them all for their (anonymous and unpaid) hard work and for helping ensure that we maintain the highest standards of scholarship.

Don Fowler, in a review article on classical journals in the Times Literary Supplement (Nov 26th 1993) wrote: 'Boyle has consistently used Ramus to offer hospitality to a wide range of new and provocative writing...Ramus is even better now than when it started, and deserves a place on the shelves of all the young and the cool.' 'Cool' I cannot promise, but new and provocative writing, and renewed energy and passion for a greater understanding of classical texts and our ways of thinking them, we can. That is still the object of Ramus and will be, for the next 35 years and beyond.

Newnham College

University of Cambridge 